\title{
Effect of Challenge Feeding on Calf Birth Weight and Cow Body Weight Gain
}

\author{
Neeraj Singh, P. A. Kahate*, R. R. Shelke, S. D. Chavan and S. P. Nage \\ Department of Animal Husbandry and Dairy Science, Dr. Panjabrao Deshmukh \\ KrishiVidyapeeth, Akola, Maharashtra-444104, India \\ *Corresponding author
}

\section{Keywords \\ Challenge feeding, Milk production, Crossbred cows, Pre-partum, Post- partum \\ Article Info \\ Accepted: \\ 12 November 2019 \\ Available Online: \\ 10 December 2019}

\section{A B S T R A C T}

The aim of present study was to find out the effect of 'challenge feeding' on performance and economics of milk yield of crossbred cows. Eighteen advance pregnant crossbred cows were selected 60 days before expected date of calving and were divided into 3 groups i.e. control $\left(T_{1}\right)$, treatment $\left(T_{2}\right)$ and $\left(T_{3}\right)$ on the basis of milk yield, parity and body weight for this study. During the pre-partum period, animals of $T_{1}$ control group were fed $1 \mathrm{~kg}$ concentrate for maintenance per day from $60^{\text {th }}$ day to prior to calving till the day of parturition. $T_{2}$ group animals were fed $1 \mathrm{~kg}$ concentrate for maintenance plus $1.5 \mathrm{~kg}$ concentrate as challenge feed per day from $60^{\text {th }}$ day to $22^{\text {nd }}$ day prior to calving and from $22^{\text {nd }}$ day prior to calving till parturition animals were fed $1 \mathrm{~kg}$ concentrate for maintenance plus $2 \mathrm{~kg}$ concentrate as challenge feed per day. $\mathrm{T}_{3}$ group animals were fed $1 \mathrm{~kg}$ concentrate for maintenance plus $2 \mathrm{~kg}$ concentrate as challenge feed per day from $60^{\text {th }}$ day to $22^{\text {nd }}$ prior to calving and from $22^{\text {nd }}$ prior to calving till parturition animals were fed $1 \mathrm{~kg}$ concentrate for maintenance plus $2.5 \mathrm{~kg}$ concentrate as challenge feed per day. During the postpartum period, animals of $T_{1}, T_{2}$ and $T_{3}$ group were fed based on their milk yield as per thumb rule i.e. $1 \mathrm{~kg}$ concentrate per day for maintenance and $1 \mathrm{~kg}$ concentrate per $2.5 \mathrm{~kg}$ of milk production. The mean DMI $(\mathrm{kg})$ in $\mathrm{T}_{1}, \mathrm{~T}_{2}$ and $\mathrm{T}_{3}$ cows during pre-partum period was $7.82,9.04$ and $10.09 \mathrm{~kg}$ respectively which did significantly between treatments. The postpartum DMI was significantly higher $(\mathrm{P}<0.05)$ in $\mathrm{T}_{3}(11.40 \mathrm{~kg})$ as compared to $\mathrm{T}_{2}$ $(10.74 \mathrm{~kg})$ and $\mathrm{T}_{1}(9.66 \mathrm{~kg})$ treatments. The overall mean daily milk yield per animal was significantly higher $(\mathrm{P}<0.05)$ in $\mathrm{T}_{3}(11.03 \mathrm{~kg})$ as compared to $\mathrm{T}_{2}(9.85 \mathrm{~kg}) \& \mathrm{~T}_{1}$ $(6.96 \mathrm{~kg})$. The difference in mean calf birth weight $\mathrm{T}_{1}, \mathrm{~T}_{2}$ and $\mathrm{T}_{3}$ was $19.9,23.5 \&$ $24.6 \mathrm{~kg}$ respectively. The overall means of body weight gain of cow in the treatment $\mathrm{T}_{1}, \mathrm{~T}_{2}$ and $\mathrm{T}_{3}$ groups were $31.33,41.33$ and $46.83 \mathrm{~kg}$, respectively. It was concluded that the practice of challenge feeding of crossbred cows improved the production performance during early lactation without affecting their periparturient health and was found to be economical. 


\section{Introduction}

India is predominantly an agriculture country as $65 \%$ of India's population is dependent on agriculture and allied activities. The population of milch crossbred animals stands at 19.42 million, in 2012 and milk production is about $16 \%$ of the total milk produced in country. In developing countries, more than $70 \%$ of the expenditure, in dairy farming is on the feeding of animals. Most of the farmers are, not aware of the benefits of quality feeding and that of balanced diet. In India, concentrate feeding to animals is neglected due to poor economic condition of farmers.

The milch animals are deprived of concentrate during dry period as well as in milking stage and thus these dairy animals are deprived of essential nutrients. These nutrients are very much essential to fulfil the requirements of growth and maintenance of Foetus, placenta, and uterus as well as to replenish the body tissue losses due to milk production postpartum. This lack of concentrate feeding along with low availability of good quality fodders is the major reason behind the poor productivity of our crossbred cattle population. Many reports are available on challenge feeding however, the information showing the effect of Challenge feeding on performance and economic of animal is good under Indian condition. The present work was under taken up to make comparative study of challenge feeding.

\section{Materials and Methods}

The present investigation entitled "Effect of challenge feeding on performance and economics of milk production of crossbred cows" was conducted at Livestock Instructional Farm, Department of Animal Husbandry \& Dairy Science, Dr. Panjabrao Deshmukh Krishi Vidyapeeth, Akola during the year 2018-2019.

\section{Selection of animals}

Eighteen pregnant crossbred cows were selected 2 months prior to calving according to data obtained from breeding records of animals. As and when available animals were selected and divided in 3 groups based on parity, body Weight and milk yield of previous lactations to maintain homogeneity among experimental animals (Table 1). The same process was adopted till there were six animals in each treatment group. The experimental animals were separated from the main herd 7-10 days before start of experiment to make the experimental animals adjust to the new environment.

\section{Duration of experiment}

The present study was conducted for a period of 60 days pre-partum to 60 days postpartum. The total duration of the experiment was approximately 6 months as all the animals were not available at the same time.

\section{Feeding and Management}

Eighteen dry pregnant crossbred cows were selected from the Dairy herd of the university on the basis of Parity, body weight, previous lactation yield and expected date of calving (Table 1). The experiment lasted 60 days prepartum and 60 days post-partum period duration. The animals divided into three equal groups were offered feed animals of $\mathrm{T}_{1}$ control group were fed $1 \mathrm{~kg}$ concentrate for maintenance per day from $60^{\text {th }}$ day to prior to calving till the day of parturition. $\mathrm{T}_{2}$ group animals were fed $1 \mathrm{~kg}$ concentrate for maintenance plus $1.5 \mathrm{~kg}$ concentrate as challenge feed per day from $60^{\text {th }}$ day to $22^{\text {nd }}$ day prior to calving and from $22^{\text {nd }}$ day prior to calving till parturition animals were fed $1 \mathrm{~kg}$ concentrate for maintenance plus $2 \mathrm{~kg}$ concentrate as challenge feed per day. $\mathrm{T}_{3}$ group animals were fed $1 \mathrm{~kg}$ concentrate for 
maintenance plus $2 \mathrm{~kg}$ concentrate as challenge feed per day from $60^{\text {th }}$ day to $22^{\text {nd }}$ prior to calving and from $22^{\text {nd }}$ prior to calving till parturition animals were fed $1 \mathrm{~kg}$ concentrate for maintenance plus $2.5 \mathrm{~kg}$ concentrate as challenge feed per day. During the postpartum period, animals of $\mathrm{T}_{1}, \mathrm{~T}_{2}$ and $\mathrm{T}_{3}$ group were fed based on their milk yield as per thumb rule i.e. $1 \mathrm{~kg}$ concentrate (Table 2) per day for maintenance and $1 \mathrm{~kg}$ concentrate per $2.5 \mathrm{~kg}$ of milk production.

The animals were fed individually. Water was available to the animal around the clock. The animals were weight twice in week before offering them any feed or fodder in morning. All the animals in both the treatment groups were maintained under uniform housing conditions.

All the animals were housed in the shed for the entire period of experiment except before 8 days of calving all the animal were transferred in the individual calving pens.

Immediately after parturition, the animals were closely watched for incidence of any metabolic disorder like parturient paresis, ketosis and other disease mastitis, which were treated accordingly by the Veterinarian.

All the Eighteen crossbred cows were milked by hand milking twice a day i.e. 6 A.M., 5 P.M. As a usual practice the animals were washed before milking. Before each milking teats and udders were massaged to initiate let down of milk. The animals were handled gently and calmly. Milk yield was recorded after each milking.

\section{Statistical analysis}

The data obtained was analyzed by Randomized Block Design (RBD) as per the procedure described by Gomez and Gomez (1984).

\section{Results and Discussion}

The results of challenge feeding of crossbred cows on DM intake, milk production, milk composition, calf birth weight, peak yield, days taken to achieve peak milk Yield, and economics of challenge feeding on milk yield.

\section{Chemical composition of feedstuffs}

The chemical composition of the different feeds used in experimental rations is presented in table 2.

\section{Dry matter intake}

The dry matter intake includes pre-partum and post-partum average daily dry matter intakes of cows in all treatment are presented in table 3 . The feed intake in crossbred cows during pre-partum period $18.00,19.58$ and $21.17 \mathrm{~kg}$ in $T_{1}, T_{2}$ and $T_{3}$ group respectively. The feed intake was significantly higher in $\mathrm{T}_{3}$ as followed by $T_{1}$ and $T_{2}$ group of cows while lowest in treatment $\mathrm{T}_{1}$. The average daily intake of dry matter during pre-partum period was $7.82,9.04$ and $10.09 \mathrm{~kg}$ per cows in $\mathrm{T}_{1}, \mathrm{~T}_{2}$ and $\mathrm{T}_{3}$ group respectively. The cows from $\mathrm{T}_{3}$ group consumed more DM than that of $\mathrm{T}_{1}$ and $\mathrm{T}_{2}$ group. Higher intake of DM per $100 \mathrm{~kg}$ body weight was observed in treatment $T_{3}$ and lowest in $T_{1}$. The present results of investigation are agreement with Vandehaar et al., (1999) and Keady et al., (2001) reported that higher feeding of regime in pre-partum periods increases the dry matter intake significantly.

The feed intake in crossbred cows during postpartum period 20.01, 21.47 and $22.64 \mathrm{~kg}$ in $\mathrm{T}_{1}, \mathrm{~T}_{2}$ and $\mathrm{T}_{3}$ respectively. The feed intake was significantly higher in $T_{3}$ as compare to $\mathrm{T}_{1}$ and $\mathrm{T}_{2}$ group respectively. The overall means of daily dry matter intake during two months of postpartum period were $9.66,10.74$ and $11.40 \mathrm{~kg}$ for $\mathrm{T}_{1}, \mathrm{~T}_{2}$ and $\mathrm{T}_{3}$ group 
respectively. The average daily dry matter intake of the $\mathrm{T}_{3}$ group was significantly higher $(\mathrm{P}<0.05)$ over the $\mathrm{T}_{1}$ and $\mathrm{T}_{2}$ group during the postpartum period. The overall mean of DMI per $100 \mathrm{~kg} \mathrm{BW}$ during the postpartum period were $3.12,3.37$ and $3.57 \mathrm{~kg}$ in $\mathrm{T}_{1}, \mathrm{~T}_{2}$ and $\mathrm{T}_{3}$ treatment groups respectively. The average daily DM intake per $100 \mathrm{~kg} \mathrm{BW}$ in treatment $\mathrm{T}_{3}$ was significantly higher as compare to $\mathrm{T}_{1}$ and $\mathrm{T}_{2}$ groups. This is might be due to increase the concentrate in challenge feeding. Postcalving DMI did not differ significantly between treatment and control group.

Table.1 Details of experimental animals

\begin{tabular}{|c|c|c|c|c|c|}
\hline Groups & $\begin{array}{l}\text { Sr. } \\
\text { No. }\end{array}$ & $\begin{array}{c}\text { Animal } \\
\text { No. }\end{array}$ & $\begin{array}{l}\text { Lactations } \\
\text { completed }\end{array}$ & $\begin{array}{l}\text { Average lactation } \\
\text { yield of previous } \\
\text { lactations (kg) }\end{array}$ & $\begin{array}{l}\text { Body weight } \\
\text { (kg) }\end{array}$ \\
\hline \multirow{6}{*}{ I } & 1 & CB- 732 & 1 & 1640 & 241 \\
\hline & 2 & CB- 696 & 2 & 1701 & 340 \\
\hline & 3 & CB- 791 & 3 & 1760 & 282 \\
\hline & 4 & CB- 779 & 2 & 1680 & 316 \\
\hline & 5 & CB- 752 & 2 & 1780 & 304 \\
\hline & 6 & CB- 756 & 1 & 1650 & 294 \\
\hline Average & & & $1.83 \pm 0.30$ & $1701.8 \pm 23.43$ & $296.16 \pm 13.69$ \\
\hline \multirow{6}{*}{ II } & 7 & CB- 695 & 3 & 1680 & 262 \\
\hline & 8 & CB- 664 & 2 & 1720 & 335 \\
\hline & 9 & CB- 772 & 1 & 1750 & 280 \\
\hline & 10 & CB- 773 & 2 & 1620 & 320 \\
\hline & 11 & CB- 757 & 3 & 1790 & 305 \\
\hline & 12 & CB- 762 & 1 & 1660 & 290 \\
\hline Average & & & $1.83 \pm 0.30$ & $1703.33 \pm 25.38$ & $298.66 \pm 10.92$ \\
\hline \multirow{6}{*}{ III } & 13 & CB- 788 & 1 & 1710 & 261 \\
\hline & 14 & CB- 731 & 3 & 1770 & 334 \\
\hline & 15 & CB- 746 & 2 & 1750 & 278 \\
\hline & 16 & CB- 730 & 2 & 1690 & 317 \\
\hline & 17 & CB- 776 & 3 & 1650 & 302 \\
\hline & 18 & CB- 778 & 1 & 1680 & 289 \\
\hline Average & & & $1.83 \pm 0.30$ & $1708.33 \pm 18.33$ & $296.83 \pm 10.82$ \\
\hline
\end{tabular}

Table.2 Chemical composition of feedstuff (\%DM) basis)

\begin{tabular}{|c|c|c|c|c|c|c|c|}
\hline Sr. No. & $\begin{array}{c}\text { Name of fodder } \\
\text { crop }\end{array}$ & $\begin{array}{c}\text { DM } \\
\mathbf{( \% )}\end{array}$ & $\begin{array}{c}\text { CP } \\
(\mathbf{\%})\end{array}$ & $\begin{array}{c}\text { CF } \\
(\mathbf{\%})\end{array}$ & $\begin{array}{c}\text { EE } \\
(\mathbf{\%})\end{array}$ & $\begin{array}{c}\text { NFE } \\
(\mathbf{\%})\end{array}$ & $\begin{array}{c}\text { Total } \\
\text { ash(\%) }\end{array}$ \\
\hline $\mathbf{1 .}$ & Berseem & 14.38 & 16.34 & 22.3 & 3.2 & 51.9 & 15.4 \\
\hline $\mathbf{2 .}$ & Maize & 23.3 & 7.9 & 28.7 & 1.9 & 48.53 & 7.0 \\
\hline $\mathbf{3 .}$ & Napier & 21.4 & 1.8 & 35.76 & 2.40 & 44.18 & 10.16 \\
\hline $\mathbf{4 .}$ & Soybean straw & 90.51 & 6.81 & 38.32 & 1.65 & 41.36 & 11.86 \\
\hline $\mathbf{5 .}$ & Concentrate & 90.80 & 17.63 & 11.68 & 2.72 & 64.08 & 3.89 \\
\hline
\end{tabular}


Table.3 Effect of challenge feeding on DM intake during pre-partum and post-partum period

\begin{tabular}{lccccccc}
\hline & $\mathrm{T}_{1}$ & $\mathrm{~T}_{2}$ & & $\mathrm{~T}_{3}$ & F-test & $\mathrm{SE}(\mathrm{m})$ & CD at 5\% \\
\hline Pre-partum DMI (kg/day) & & & & & & \\
Average daily feed intake & 18.00 & 19.58 & 21.17 & Sig. & 0.20 & 0.60 \\
Average DMI & 7.82 & 9.04 & 10.09 & Sig. & 0.01 & 0.04 \\
Average DMI/100kg BW & 2.55 & 2.84 & 3.16 & Sig. & 0.04 & 0.12 \\
Post-partum DMI (kg/day) & & & & & & \\
Average daily feed intake & 20.01 & 21.47 & 22.64 & Sig. & 0.12 & 0.40 \\
Average DMI & 9.66 & 10.74 & 11.40 & Sig. & 0.02 & 0.08 \\
Average DMI/100kg BW & 3.12 & 3.37 & 3.58 & Sig. & 0.04 & 0.12 \\
\hline
\end{tabular}

Table.4 Effect of challenge feeding on calf birth weight, BW gain of cow and Milk production

\begin{tabular}{lcccccc}
\hline & $\mathbf{T}_{1}$ & $\mathbf{T}_{2}$ & $\mathbf{T}_{3}$ & F-test & SE(m) & CD at 5\% \\
\hline Average calf birth weight $(\mathrm{kg})$ & 19.90 & 23.50 & 24.60 & Sig. & 0.28 & 0.91 \\
Average BW gain of cow (kg) & 31.33 & 41.33 & 46.83 & Sig. & 0.56 & 1.79 \\
Increase in calf birth weight & - & 18.09 & 23.61 & - & - & - \\
Over control (\%) & & & & & & \\
\hline
\end{tabular}

Table.5 Economics of challenge feeding in crossbred cows

\begin{tabular}{|c|c|c|c|}
\hline \multirow[t]{2}{*}{ Particulars } & \multicolumn{3}{|c|}{ Treatments } \\
\hline & $\mathbf{T}_{1}$ & $\mathbf{T}_{2}$ & $\mathbf{T}_{\mathbf{3}}$ \\
\hline $\begin{array}{l}\text { Total concentrate mixture consumed during } \\
\text { pre-partum period (kg) }\end{array}$ & 60 & 160.5 & 190.5 \\
\hline Cost of total concentrate mixture (Rs. 20/ kg) & 1200 & 3210 & 3810 \\
\hline Cost of concentrate mixture over control group & -- & 2010 & 2610 \\
\hline Average calf weight & 19.9 & 23.5 & 24.6 \\
\hline $\begin{array}{l}\text { Percent increase of calf weight over control } \\
\text { group }\end{array}$ & -- & 18.09 & 23.61 \\
\hline Average cow body weight gain & 31.33 & 41.33 & 46.83 \\
\hline Increase body wt. gain over control group & -- & 10.00 & 15.50 \\
\hline
\end{tabular}

The present results of investigation are agreement with Agenas et al., (2003) reported that the prepartum DMI corresponded well with the experimental design but there was no significant difference in postpartum DMI of the three treatment groups. Dann et al., (2006) observed that the cows that were given the highest plane of nutrition prepartum had lowest DMI postpartum. Guo et al., (2007) reported that Post-calving DMI did not differ significantly between treatment and control group.
Calf birth weight and body weight gain of cow

The mean birth weights of calves in all treatment groups were $19.9 \pm 0.35,23.5 \pm 0.22$ and $24.6 \pm 0.24 \mathrm{~kg}$ respectively. The calves born to cows of challenge fed group $\mathrm{T}_{2}$ and $\mathrm{T}_{3}$ were about 3.6 and $4.67 \mathrm{~kg}$ heavier than calves born to cows of $\mathrm{T}_{1}$ group and statistically the difference was significant. The birth weight of calves was increased by 18.09 and 23.61 percent in treatment $T_{2}$ and $T_{3}$ group 
respectively. The result of this experiment regarding birth weight agreement with the findings of Kale (1984), Usmani and Inskeep (1989), Chokhataridi (1995), Singh et al., (2003) and Das et al., (2007) reported that increased feeding of challenge feeds before calving increased average body weight of calves.

From the table 4 revealed that the total body weight gains of cow in the treatment were $T_{1}$, $\mathrm{T}_{2}$ and $\mathrm{T}_{3}$ groups were $31.33,41.33$ and 46.83 $\mathrm{kg}$ respectively. The live weight of all the animals, at $60 \mathrm{~d}$ pre-partum, was comparable, thereafter; it increased linearly in all the groups. The average body weights one day before calving were significantly higher $(\mathrm{P}<0.05)$ in $\mathrm{T}_{2}$ and $\mathrm{T}_{3}$ increases significantly $(\mathrm{P}<0.05)$ in all weeks

\section{Economics of challenge feeding}

The total concentrate mixture consumed during pre-partum period in $\mathrm{T}_{1}, \mathrm{~T}_{2}$ and $\mathrm{T}_{3}$ group 60, 160.5 and $190.5 \mathrm{~kg}$ respectively. Since the cost of concentrate mixture 1200, 3210, and 3810 in $T_{1}, T_{2}$ and $T_{3}$ group respectively. In treatment group increase calf birth weight over control group in 18.09 and 23.61 percent in $T_{2} \& T_{3}$ group respectively. Body weight gain of cow over control group 10.00 and $15.50 \mathrm{~kg}$ in $\mathrm{T}_{2}$ and $\mathrm{T}_{3}$ group respectively (Table 5).

The practice of challenge feeding of crossbred cows improved the production performance and calf birth weight during early lactation without affecting their peri-parturient health and calf birth weight increased $T_{2}$ and $T_{3}$ group over control group by 18.09 and 23.61 per cent respectively. The practice of challenge feeding was found economical in view of cost of per litre of milk production. The cost of milk production per litre in $\mathrm{T}_{1}, \mathrm{~T}_{2}$ and $\mathrm{T}_{3}$ were 25.90, 23.79 and 23.72 during the early stage of lactation

\section{Acknowledgments}

The authors acknowledged the Dean (Agriculture), Dr. PDKV, Akola, Associate Dean, Post Graduate Institute and Head Department of Animal Husbandry and Dairy Science, Dr. Panjabrao Deshmukh Krishi Vidyapeeth, Akola (MS) providing necessary facility and support to carry out this research work.

\section{References}

Agenas, S., Burstedt, E. and Holtenius, K. 2003. Effects of feeding intensity during the dry period. 1. Feed intake, bodyweight, and milk production. J. Dairy Sci. 86:870-882.

Dann, H.M., Litherland, N.B., Underwood, J.P., Bionaz, M., D'Angelo, A., McFadden, J.W., and Drackley, J.K. 2006. Diets during far-off and closeup dry periods affect periparturient metabolism and lactation in multiparous cows. J. Dairy Sci. 89: 3563-3577.

Das, K.S., Das, N. and Ravikumar, G.V.P.P. 2007.Effect of 'steaming-up' on subsequent production in dairy cows. Indian Journal of Animal Sciences.77 (7): 583-585.

Gomez, K.A. and Gomez; A.A. 1984. Statistical procedure for agriculture research, second, ed. John willy and sons, New York.

Guo, J., Peters, R.R. and Kohn, R.A. 2007. Effect of a Transition Diet on Production Performance and Metabolism in Periparturient Dairy Cows. J. Dairy Sci. 90:5247-5258.

Kale, M.M. 1984.Effects of Prepartum Feeding on the Postpartum Performance of Crossbred Cows. M.Sc. Unpublished Dissertation, Kurukshetra University, Kurukshetra, India. 
Keady, T.W.J., Mayne, C.S., Fitzpatrick, D.A. and McCoy, M.A. 2001. Effect of concentrate feed level in late gestation on subsequent milk yield, milk composition, and fertility of dairy cows. J. Dairy Sci. 84:1468- 1479.

Singh, J., Singh, B., Wadhwa, M. and Bakshi, M.P.S. 2003.Effect of level of feeding on the performance of crossbred cows during pre-and post-partum periods.Asian Australasian Journal of Animal Science. 16 (12):1749-54.

Skorba, A.V. 1995. The effect of different feeding levels for pregnant cows on reproductive ability and subsequent milk production. Anim. Breed. Abstr.63 (4): 1504.

Usmani, R. H. and Inskeep, E.K. 1989. Effect of prepartum feeding on milk yield and calf growth rate in limited suckled and non-suckled buffaloes. J. Dairy Sci. 72:2087-2094.

Vandehaar, M.J., Yousif, G., Sharma, B.K., Herdt, T.H., Emery, R.S., Allen, M.S. and Liesman, J.S. 1999. Effect of energy and protein density of prepartum diets on fat and protein metabolism of dairy cattle in the periparturient period. J. Dairy Sci. 82:1282-1295

\section{How to cite this article:}

Neeraj Singh, P. A. Kahate, R. R. Shelke, S. D. Chavan and Nage, S. P. 2019. Effect of Challenge Feeding on Calf Birth Weight and Cow Body Weight Gain. Int.J.Curr.Microbiol.App.Sci. 8(12): 1616-1622. doi: https://doi.org/10.20546/ijcmas.2019.812.194 